\title{
Managerial Analysis of the Attraction of FDI in Canada
}

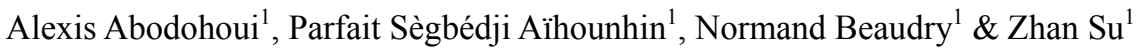 \\ ${ }^{1}$ School of Management, University Laval, Canada \\ Correspondence: Alexis Abodohoui, School of Management, University Laval, 2325 rue de Terrasse, Québec \\ G1V 0A6, Canada. Tel: 1-581-990-8282. E-mail: alexis.abodohoui.1@ulaval.ca
}

$\begin{array}{ll}\text { Received: December 19, } 2014 & \text { Accepted: January 20, } 2014 \quad \text { Online Published: February 27, } 2015 \\ \text { doi:10.5539/ijbm.v10n3p34 } & \text { URL: http://dx.doi.org/10.5539/ijbm.v10n3p34 }\end{array}$

\begin{abstract}
This research is an analytical synthesis of managerial strategies for attracting Foreign Direct Investment (FDI) in Canada. It establishes from a literature review different strategies devoted to the issues and benefits of FDI relative to the capitalization of FDI in Canada. In terms of contributions of the study, we propose a theoretical basis that could allow managers, entrepreneurs, and policy makers to make appropriate decisions regarding the choice of investment sites. This review highlights the importance of FDI attraction policy in Canada. Results suggest that there are too many variables (image of country, market Size, infrastructure, cost of inputs, transaction cost, resources, and ethics) that need to be considered when selecting a site for investments. Implications of the research and limitation have been provided.
\end{abstract}

Keywords: attraction, FDI, strategy, Canada

\section{Introduction}

In 1960, foreign investment was regarded with distrust and suspicion by both industrialized countries and developing ones (Deblock \& Rioux, 2010). The reasons for this apprehension are related to the preservation of national sovereignty. Economists have developed theories of attraction that advocated self-directed development strategies based on import substitution with the rule of the role of the state (Hirschman, 1988; Myrdal \& Sitohang, 1957; Woodward, 2009). Today, the situation has changed and most countries of the world have turned to the attraction and promotion of international investment. This attraction may be sectorial or even national. Canada is not indifferent vis-a-vis foreign direct investment. Currently, with the strategies for attracting FDI and economic integration, governments continue to implement sound policies to ensure a real economic engine in the development of the industrial fabric.

In the report of the International Trade of Canada for the year 2012, Ed Fast (Note 1) has made it clear that for the average Canadian, it would be very difficult to imagine a world without international trade. Trade enriches our lives in so many ways and through so many direct and indirect channels it would be virtually impossible to separate the effects or accurately measure the benefits and convenience it brings: Minister Van Loan (Note 2) also added that Canada's economy is among the fastest growing and most innovative in the world, so that Canada is able to offer many advantages as a trading partner and investment destination. That is, foreign investments are full of benefits that can be realized not only by capital inflows to the host country, but also by a contribution of technology and know-how and access to new markets (Barthel, Busse, \& Neumayer, 2010; Busse, Königer, \& Nunnenkamp, 2010; Kumar \& Siddharthan, 2013).

\section{Literature Review}

\subsection{Socio-Economic and Institutional Contributions of FDI}

In this part of our research we analyze more specifically the contributions of FDI on the socio-economic and technological growth in the province of Quebec. There are many policies that form part of wider strategies and measures to improve macroeconomic conditions, increase skills, build infrastructure and promote business development. All these measures are very important to make it more visible and the country needs tangible actions to know to exploit it profitably. FDI add several important components politico institutional factors that determine FDI flows and thus they contribute to increasing the attractiveness of the host country. It is a tool that allows improving the attractiveness of the host country for foreign investors in the sense that a good strategy compared to FDI removes barriers to FDI such as domestic regulation of services. It also contributes to the geographical enlargement or deepening of integration resulting from the elimination of restrictions or barriers to 
competition between companies or harmonization of competition policies (Bevan \& Estrin, 2004). As trade is liberalized, investors have access to large markets. The implementation of new products and increased competition enter the domestic market. The resulting distribution of resources contributes to increase the economic well-being of society, or at least the country. In Canada, the FDI also help directly to create employment in sectors that produce goods and services and, indirectly, in the exportation activities. In fact, one in five jobs in Canada depends directly or indirectly exports (Department of Foreign Affairs and International Trade, 2012). FDI solve problems by providing not only valuable capital to stimulate growth and development, but also technologies, skills and access to foreign markets. Indeed, the attraction and retention of FDI can also have a significant impact on the host communities in terms of employment, productivity and skills and the transfer of knowledge (Monaghan, 2012).

\subsection{FDI, Transfer and Diffusion of Technology}

Whether a transfer internalized (between a parent and a foreign subsidiary that belongs to and is controlled by it) externalized (between a multinational company and an entity it does not control); the role of FDI in technology transfer in developing countries is undeniable. Canada is a country with a lot of capacity to absorb technology. This is very useful for manufacturing industries. The transfer of knowledge and technology enables more rapid introduction of new technologies and facilitates access to markets and networks of regional or global production. It gives access to a large possibility of technologies and organizational skills in the host country (Kumar, 1998, 2009). Transfer of technology also improves the process of development and modernization of local technology. The FDI allows the diffusion of technological innovations in that it helps to provide high-tech goods for production. It promotes intercultural communication between countries. Musolesi (2006), in a study of 16 OECD countries, determined the true extent of the relationship between different stocks of knowledge, including "those foreign conveyed between countries through trade flows, and total factor productivity. He concludes that direct investment in a country acts positively on public research and academic research.

\subsection{FDI and Management of Climate Change}

Climate change is disrupting all development policies. Now we must consider all development plans integrating adaptation measures and mitigation. Most FDI primarily aim at the exploitation of the host country's natural resources. In recent decades, there has been a rapid development of the mining of construction materials, mineral sands, mining resources, gravel beaches, as well as natural gas and wood in all countries especially in Africa and Canada. These operations affect the environment indelibly, damaging the land and water, reducing the fertility of formerly arable land and also jeopardize the livelihoods present and future of the generations. Nowadays, all countries want to attract FDI. But they should also protect against investments that are harmful to the fight against poverty, environmental protection and the fight against climate change. A good development strategy must ensure a health environmental.

\subsection{Treatment Issues Related to FDI, Transparency, Predictability and Stability of Nations}

Some countries integrate their investment policy in partnership agreements. The U.S. model (NAFTA) concluded by the United States and Canada liberalized foreign investment by eliminating or easing some restrictions on the employment of expatriates and banning a number of performance requirements (Allee \& Peinhardt, 2010; Woolcock, 2006). These agreements secure business relationships between countries and are additional to investment success guarantees. In this context, Canada has signed several agreements with different countries. Under these partnerships, foreign investors are treated on an equal footing and no less favorably than domestic investors with respect to the establishment, acquisition, expansion, management, conduct, operation and sale or other dispositions of investments. They also give privileges to members and maintain restrictive measures in areas where they have made commitments. The International Investment Agreements (IIA) and Treated Bilateral Investment (TBI) introduce several important elements in the regime of FDI, thereby enhancing their appeal to these foreign investors. They improve the protection of investment security, transparency, stability and predictability of the investment regime. They reinforce the geographical expansion of a regional integration program (UNCTAD, 2003). Agreements are favorable to the development of a multilateral framework to secure transparent and predictable conditions for foreign direct investment. A multilateral framework could significantly increase the transparency and predictability and safety rules in force in each member country. Another important advantage is that FDI through agreements contribute to strengthening cultural ties. Thus, culture is also the key to development in the sense that the interactions enhanced by FDI is "a cultural reality in the broadest sense of the lifestyles, thought and actions, knowledge and expertise, value systems" (Fabrizio, 1994).

\subsection{Issues of FDI Relative to the Strategy of Re-Industrialization}

In the era of globalization and liberalization of markets, the objective of all governments is to achieve economic 
growth by opening their markets to foreign investors and protecting their national companies. However, for reasons of national security, political and social reasons, these policymakers express disdain when foreign investors try to take control corporate established in their territory. It is obvious that investors can get to control the economy of a country, but governments need to develop a more sensible strategy. In addition, it is important to mention that the investment agreements should take into account the economic potentials of the country to restore the normative autonomy of political powers. This is because of certain agreements; some governments are forced to resort to privatization of public assets, deregulation, liberalization of prices, and the reform of social policies to adjust the internal dimension of governance and meet requirements subscribed to externally.

\subsection{FDI: Trends}

An FDI is an investment to acquire a lasting interest in an enterprise operating outside of the economy of the investor. Moreover, in the case of FDI, the goal of the investor is to obtain a significant role in the management of the enterprise (UNCTAD, 2012, Note 3). Among the trends identified by UNCTAD on the flow of FDI in recent years include two significant items. First, a decrease in the amount of FDI in developed countries and an increase to developing countries. Among the latter, note that China is now cited as the favorite country for the investment destination, according to data provided by UNCTAD (UNCTAD, 2012). Finally, the report on global investment reports another important trend which is new and intensified efforts to promote foreign investment. The global crisis of 2008 was the trigger for this intensification. Indeed, on a background of economic uncertainty, financial market turbulence and anemic growth, many countries continue to liberalize and promote foreign investment as a means of supporting economic growth and development (UNCTAD, 2012).

Overall, there has been a steady growth both for incoming and outgoing FDI. For example, Canadian direct investment abroad rose from 2002 to 2013, from more than 400 billion Canadian dollars to just under 800 billion Canadian dollars. This is equivalent to a growth of more than $100 \%$. In the same vein, the level of foreign direct investment in Canada has varied at a similar pace over the same period from to around 350 billion to $\$ 600$ billion Canadian dollars, or a variation more than $50 \%$. But a more accurate reading shows that in fact, the balance of net assets in Canadian direct investment has not changed too much over the same period. These data from Statistics Canada tend to support the need to better consider the strategies for attracting FDI in Canada, and our proposal for a grid to attract foreign investment.

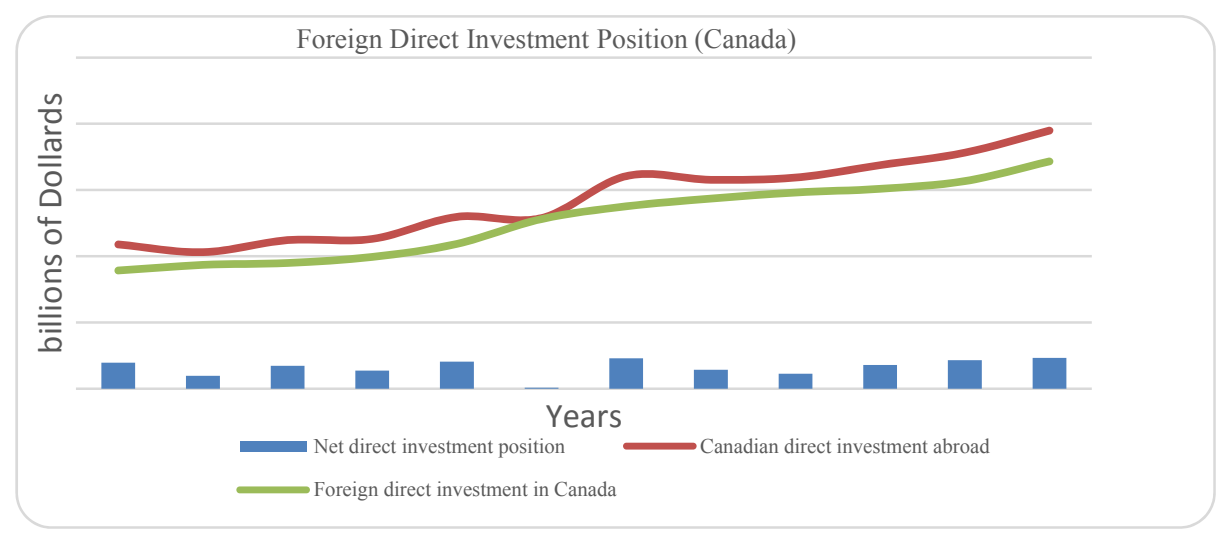

Figure 1. Foreign direct investment position in Canada

\subsection{Strategies for Attracting FDI}

Historically, the question of the location of FDI was rather explored from the perspective of the multinational enterprises. In contrast to the prospect of attracting FDI, which is promoter by the state, it is rather a perspective on the choice of location for FDI, a Small Medium Enterprise (SME). For, Dunning (1998), the choice of location is determined by various benefits this location. For example, a company looking to great efficiency in production would work at sites providing inputs at lower costs. According to research by Porter $(1985,1990$, 1998), the attractiveness of a location for a multinational company is based primarily on its ability to increase the competitive advantage of the company. More specifically, factors such as the network transport and communication (physical infrastructure), skilled labor (human resources) as well as learning opportunities are decisive in the choice of a location. Note that these elements are primarily environmental. McCann and Mudambi (2004) argue that the perspective provided by Porter completes the vision of a widely accepted ecliptic 
paradigm of Dunning as "OLI (Ownership, Location and Internalization)" about the location of multinational companies. According to the authors, there is no consistent and current vision of "location theory" but rather in the literature there is a gap between the traditional view of the "rent theory" and research "international business". In this sense, research in international management could gain by integrating the perspectives developed by the specialists of regional development and economic geography.

According to (Monaghan (2012), these are the characteristics of a local environment within the content of sub-national levels that become increasingly important to the siting and location of multinationals. At the local level, the author stresses the importance of the network of local organizations in attracting FDI. Based on the case of Ireland, the author lists the different actors playing a role in attracting FDI to a specific sub-region; or for national and regional entities, such as regional development agencies, educational institutions, private service providers, specific entities to a sector or industry (e.g. chambers of commerce) and other multinationals.

In terms of actions that can be taken by a government to attract FDI, Wilkinson and Brouthers (2000) found that trade missions organized by the government or other bodies of investment attraction are an effective way to increase FDI , but only for states that are already considered favorable for these investments by foreign firms . For cons, the authors state that a government policy, although a positive action for increasing FDI will have a marginal effect. Indeed, other factors are more determinants of FDI attraction benefits. According to Kotabe (1993), activities to increase exports of U.S. firms have rather had the effect of attracting foreign investment (Japanese in this case). The author also found that the presence of an office to promote a U.S. state in Japan did not affect the increase in Japanese FDI to this state.

It is interesting to note that for some researchers (Sinanagić, Čivić, \& Kamarić, 2012), the home environment is a standard that is much more important in attracting FDI that the actions taken by a government authority by the same reason. According to these researchers, improving the image of a country as a location for FDI first passes through a favorable business climate and a coherent approach by the various public actors. In this sense, they believe, particularly in developing countries that public money should be used to improve infrastructure, fight against corruption, finance corporate and create job rather than on marketing instead (logo design and advertising campaign). This perspective is consistent with the work of Brossard (1998), who explored in detail the role played by organizations promoting investment in the investment decisions of foreign firms. According to the author, the basic decision is based primarily on the competitive conditions of a location and these conditions cannot be replaced by a marketing technique. From the point of view of the investor, location is seen as a set of associated attributes i) primary investment motivations (market, cost, competence), ii) and iii) secondary benefits services to investors. The author found that OIP (Organization of Investment Promotion) have an important role to play an FDI, a necessary role, but not enough. More specifically, the services provided by OIP that are the most popular are providing key information on the location and to serve as a one stop shop for government services that the investor needs. Finally, the author found that smaller investors also appreciated the service support by the staff.

According Mucchielli (1998), one of the FDI attraction strategies put forward by different countries is the use of national agencies to promote investment. According to the author, the promotional activities of these agencies have three objectives: 1) Improve the image of the host country within the international investment community [...] 2) Directly generate inputs and locations of foreign investors [... 3 ) Provide a number of services and hospitality to potential investors and effective capacity. To achieve these objectives, the author identifies various media such as advertising, participation in trade fairs, information missions, telemarketing, canvassing, monitoring of implementation, etc. The first point raised by Mucchielli is also the subject of a further impact on the image of the country in attracting FDI. On this subject, Kalamova and Konrad (2010) find that there is a real difference between picture and even a stereotype of a country and its ability to attract FDI. One example cited is that a stereotype such as "made in Germany things are good qualities" could have a positive impact on the ability of Germany to attract FDI. Indeed, if a U.S. company wants to deploy in Europe to produce an object whose quality must be high, Germany could be considered, ceteris paribus, as advantageous compared to other countries .

Finally, note that according to several authors (Johnson, Toledano, Strauss, \& James, 2013; Mayer \& Mucchielli, 1999; Thomas, 2007, 2011), there is an increasingly strong competition among states to attract foreign investment. This competition is such that codes of conduct have been proposed in particular within the European community. Similarly, Canada has established a code of conduct to ensure that provinces do not engage in undue competition among themselves for attracting FDI. The results of such codes of conduct, however, seem to give limited results. Castells (2011) noted the same tendency to compete for FDI attraction within the same country or region. Incentives of the regional authorities are a key factor in selecting an investment location for many 
businesses (see also Gadille, Méhaut, \& Courault, 2013). According to Dunning (2009) Dunning (1998, 2009), different kinds of incentives are needed to attract different types of investments . Similarly, the determinants of investment vary according to the type of activity of a firm. One directed at the exploitation of natural resources for export will pay less attention to the size of the local market, while the EM which aims to open an R \& D would seek a type of hand work and very particular infrastructure.

\subsection{Determinants of FDI}

According to research by Kotabe (1993) on Japanese FDI in various U.S. states, one of the key elements is the presence of other Japanese firms in the state. Shaver (1998) identified in turn several elements affecting the choice of location of FDI in the US. These determinants include the coastal part of the state (location), the low level of unionization, less restrictive legal context, lower wages, the level of economic activity, income tax and state aid to international activities. Latest studies such as Blonigen (2005) has focused on identifying factors external to the EM as determinants of FDI. Among them, the tax received great attention in the literature, but, according to the author, is relatively inconsequential. The quality of institutions particularly in less developed countries is considered as an important determinant. It is closer to the concept of country risk (Amewokunu $\& \mathrm{Su}$, 2009), as the author discusses the link between weak legal protections and greater risks (expropriation cost of corruption, etc.). In addition, the author mentions a direct link between weak institutions and poor infrastructure, leading to lower profitability. Other key element is customs barriers, whose presence triggers a substitution effect of exports by opening subsidiaries abroad. Finally, Blonigen identified a critical presence of clusters that could positively impact the companies. One advantage of these business groups within the same country working in the same industry is that it facilitates the exchange of information, as well as lowering the cost of implementation and operation. However, we can also link this item to the idea of mimicry invoked by Kotabe.

Table 1. Determinants of FDI by isomorphic pressures adopted from Francis and Zheng (2009)

\begin{tabular}{lll}
\hline Isomorphic pressures & Levels of analysis & \\
\hline Coercive & Country & enterprise \\
& Laws constraining, ownership between & MNE rules mandating organizational \\
Mimetic & country transfers and operational control & practices \\
& Imitation of successful country entrants & $\begin{array}{l}\text { Imitation of MNE siblings and previous } \\
\text { entries }\end{array}$ \\
Normative & Cultural expectations within host country & $\begin{array}{l}\text { MNE control mechanisms and shared } \\
\text { beliefs }\end{array}$ \\
\hline & Primary influences at initial entry & $\begin{array}{l}\text { Primary influences for Subsequent } \\
\text { entry }\end{array}$ \\
\hline
\end{tabular}

The approach of institutional theory is interesting to identifying determinants in a host of factors. Francis and Zheng (2009) identified nine pressure levels called isomorphic pressure on multinational companies (Figure 1) which may result in the choice of FDI as an entry mode. These pressures can be coercive, mimetic or normative and come either from the host country, industry or firm.

It is also important to note that foreign direct investment can occur in the context of relocation activity. In such a case, a FDI is to the detriment of the country where were housed the activities of the MNE. On this subject, Birkinshaw, Braunerhjelm, Holm, and Terjesen (2006) identifie several determinants of FDI attractiveness from the relocation of a business headquarters or a parent. According to the authors, making it an attractive location for such relocation is based on two main elements namely industrial agglomeration and business environment more favorable than that of the host country. The author shows different elements characterizing a favorable climate, including the level of rivalry between competitors within the industry, the presence of qualified suppliers, the quality of government policies; and relations between politicians and the business sector, as well as proximity to the financial industry (banking and investment).

\section{Methodology}

Research on investment in Canada occupies a prime place in the economic recovery strategies and industrialization. Many scientific journals daily publish reports of academic and research studies on the issues and challenges of attracting investment into Canada. As part of this research, identified the relevant literature, we sought significant academic resources online in French and English without geographical or time limit. The databases searched were Academic search, JSTOR (Journal Storage), ABI / Inform, Francis and Cairn. To this 
list we added some books and research reports that deal specifically with foreign direct investment. It is neither a systematic literature review nor a traditional literature review or meta-analysis. We adopted an integrative review (Burke \& Hutchins, 2007; Kristof, 1996; Melville, Kraemer, \& Gurbaxani, 2004) that allowed us to carefully identify the relevant sections relating to our theme. Thus, at the beginning of research, we initiated a search using keywords such as Canada, investment attraction and industrialization. The databases have provided a total of one hundred articles after duplicate analysis and extraction of some research that focus on research fields other than FDI. Comprised of a team of three colleagues, we each had scrutinized the items selected to develop a conceptual base developed. Also, we examined selected article on each of the challenges and issues that present FDI in Canada articles. We wanted as part of this work to make our contributions to the theme of managing the attraction of FDI in Canada because there is few studies in the literature on FDI attraction. The items were grouped into four categories: (1) socio-economic contributions of FDI; (2) FDI as a source of dissemination and transfer of knowledge and technology; (3) strategies to attract FDI; and (4) the determinants of FDI. These four categories were created retrospectively on the basis of theories on investment due to the absence of official coding. This is a strategy used in management science (Schuler, Dowling, \& De Cieri, 1993).

\section{Contributions of Research}

\subsection{Model of FDI Attraction}

Compared to the previous literature review, in this paper we have attempted to present a comprehensive model of FDI attraction. This model presents the phenomenon of FDI attraction with a double perspective. Indeed, this model takes into account two main actors namely the multinational firm and the site location. On the one hand, the government is subject to various pressures to meet objectives such as economic development, job creation, etc. One way to achieve these goals is the attraction of FDI. So the government has two main elements that shape its strategy of attracting FDI. First, it must establish a favorable host environment for these investments. Then it can be used for marketing activities (work on the image of the country / city ..., participation in trade fairs, etc.). Then note that the MNE are also subject to various pressures that encourage them to use FDI as a means penetrating foreign markets. Finally, we note that usually a third party may be needed to explain government strategies to the investment of companies. Indeed, it is often development and investment attraction agencies that have the task of deploying the government strategies of attracting FDI through such means as the development of the home environment and facilitation of contacts between the MNE and the local government.

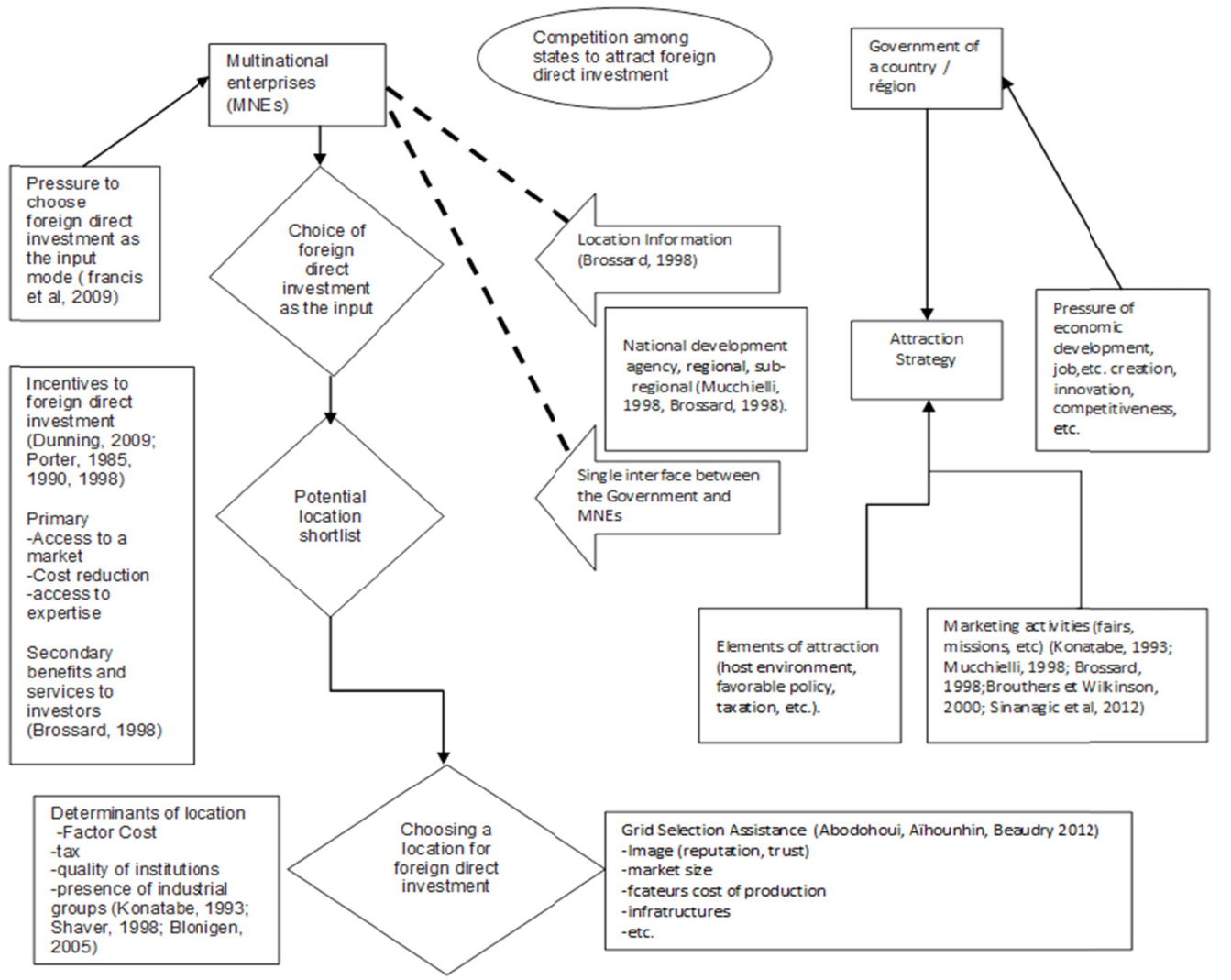

Figure 2. Model of FDI attraction 


\section{Strategy Canadian FDI Attraction}

In all countries, the added value of Foreign Direct Investment (FDI) is popular, and it is important to rely on multinationals through their investments and transfers of technologies of companies are associated to achieve the goals of economic growth. For all cities in the world attracting foreign direct investment is a source of income and officials at various levels as well as the inhabitants of the regions concerned shall make every effort to attract investors. Speaking on the issue, Hatem thinks territories need multinational companies, in turn, and these companies need Territories (Hatem, 2004). This observation of the author meaningful and can be interpreted according to one's understanding person's knowledge. Making available an area or areas for foreign companies wishing to invest would not be enough to resolve the issue. In addition to the available resources companies will require an attraction strategy and an effective strategic positioning to the city or country wishing to attract businesses in order to get them to take the decision to internationalize by investing in the country. In this context, many theories and approaches have been developed the information on the process of internationalization of companies or firms. Among other studies, we can distinguish Uppsala model which allows the learning opportunities to the firm and provides experiences which decrease with time, distance psychic process approach, and allows increasing involvement outside national borders (Casillas \& Acedo, 2013; Johanson \& Vahlne, 1977; Johanson \& Wiedersheim-Paul, 1975; Kogut, 1988; Vahlne, Ivarsson, \& Johanson, 2011) the resource-based theory which is quite analytical and focused on international business development through the financial and managerial resources (Mutinelli \& Piscitello, 1998). Dunning's eclectic paradigm approach is a integrative theory that links specific factors to the firm and the market to suggest an approach to international production; related to the development stage of the product (Acemoglu \& Robinson, 2005). Other authors broaden the strategic scope (Mucchielli, 1991). Finally there are also approaches that advocate the inclusion of the behavior of competitors to companies (Aussilloux, 1997). This means that the strategies to attract foreign direct investments must consider, and this according to the case, all these theories and see how to apply them in order to adopt the necessary strategic position that responds to requirements and conditionality's that can help mobilize and direct resources to their respective countries. To do this, in some cities and countries we proceed to the definition of policies and strategies needed to promote the creation of zones often called zones to enable investors to settle there.

In this context, the Government of Canada launched several years ago policies to promote foreign direct investment leading to the strengthening of attractiveness factors to best meet the new demands and expectations of multinational companies. Canadian provinces are not spared this perpetual quest for resources to improve the strength of their economy and the lives of their inhabitants. Canada recognizes that many countries give priority to their industrial policies to in one way or another attract FDI.

Proud of the wealth of its natural resources, the country uses this advantage to build a fairly specific attraction strategy. Recognizing that companies seek to take advantage of various benefits attached to various locations where they hope to find the best resources. Canada stands out from its competitors by using these forest and mineral resources to attract FDI. For example, over $60 \%$ of newsprint consumed in the northeast of the United States comes from the Canada pulp and paper industries. To successfully establish itself in this sector compared to its competitors. Canada had set a policy of attraction of FDI which is contained in its strategic development document. This document and the guidelines it contains are implemented by the Government of Canada while being attentive to the role played by different actors. Given the importance of foreign investment and their impact on economic development, the implementation of this strategy requires concerted action of local actors for increased performance. A section of the strategy to attract FDI is used by Canada in the context of the selection of foreign firms for carrying out activities whose skills come from other countries. Here, following international calls for public tenders, many companies find themselves in competition. The strategy used by Canada to select the best companies is a novel approach which can be summarized in three steps: 1) to be qualified (the selection is made on the basis of technical and financial offers that are written with the quality and technical qualification necessary to promote the company concerned); 2) To be stand out (all useful and necessary steps are taken to facilitate the achievement of the following phase); 3) To win (normally by the successful bidder to sign the contract and execute it). This strategy is a winning strategy in the sense that Canada maximizes the selection of the "finest" of companies to offer better services to her people. Also, Canada makes available to investors who desire all the requirements for whatever combinations of investors in selecting the host country, this country can emerge victorious. Moreover, it has the option of sectorial strategies to focus on each of these key sectors. This strategy which is published by the government focuses on the goals to be achieved and measures for the development and promotion of the strategy arebased on three orientations. :

- $\quad$ Create wealth and prepare for the future of the mineral sector; 
- $\quad$ Ensure a friendly mineral development environment;

- Foster a partnership with the communities and integrate it into the development environment.

By defining this strategy, Canada has the means to increase the benefits for the economy. The strategy should also help to modernize the framework for minerals to make it competitive and more attractive for young workers while respecting the environment. Always within the framework of the implementation of strategies to attract foreign direct investment, the New Technologies of Information and Communication (NTIC) are sufficiently used. To this end, all the information necessary for investment are made available via internet, and adequate staff is available at any time to supply additional information when needed. On some websites, the same information is made available in a dozen languages that are the most spoken in the world. Canada has information readily available on all investment sectors and attractive condition. In addition, resources are available as part of the support of investors, the key is that the areas of investments correspond to the interests of Canada. The country offers opportunities for exploration to all companies wishing to invest in order to allow them to see firsthand the availability of resources. In this context, millions of dollars are voted annually and are available through commercial banks for investors. Also, as part of the attraction of FDI policies, different laws need to be passed and published to improve the activities of companies. In addition, we can say that new legislation has been adopted favoring the promotion of brands across Canada. The texts that highlight key areas and offers new initiatives include:

- Champions program of investment: This is a program where business leaders are selected to present relevant information on partnership opportunities with Canadian companies to potential investors. These selected individuals who are also in the field should be able to attract potential investors to specific events across Canada and enrich the tour route of the investors in Canada.

- Investment Promotion Tools: These are tools that help to demonstrate, supporting analysis, the merits of establishing partnerships with Canadian companies from different sectors. This initiative also enables Canadian participation in international symposia involving influential business leaders.

post- investment Services : This program provides a special way to the foreign investor who is established in Canada to expand them network of contacts with suppliers, professionals, workers and others he would need and to provide solutions to the problems facing him.

\section{Managerial Implications of the Study}

Under the review of the literature with reference to the concept of choice of investment location, we propose a theoretical framework that could serve as a basis for selection of sites for investment for both companies by the various States under the attraction of FDI. The advantage of the framework lies in the fact that the structures and services states can use it to precisely the information investors need to make a decision.

Table 2. Theoretical basis for site selection

\begin{tabular}{|c|c|c|c|}
\hline Variables & Theories & Content of the theory & Authors \\
\hline Image & The pyramid of fame & Awareness Reputation & $\begin{array}{l}\text { (Lendrevie, Levy et Lindon, } \\
\text { Mercator, Dalloz, 2003) }\end{array}$ \\
\hline $\begin{array}{l}\text { Market Size } \\
\text { Infrastructure } \\
\text { Cost of inputs }\end{array}$ & $\begin{array}{l}\text { Eclectic paradigm of } \\
\text { Dunning }\end{array}$ & $\begin{array}{l}\text { Approach that links the factors of firm market to } \\
\text { suggest a theory of international production }\end{array}$ & $\begin{array}{l}\text { (Dunning, 1998; Dunning, 2009; } \\
\text { Agarwal et Ramaswami, 1992; } \\
\text { Driscoll et Paliwoda, 1997) }\end{array}$ \\
\hline $\begin{array}{l}\text { Transaction } \\
\text { cost }\end{array}$ & $\begin{array}{l}\text { Theories of transaction } \\
\text { costs and new theory of } \\
\text { the firm }\end{array}$ & $\begin{array}{l}\text { Normative approach following a logic of efficiency to } \\
\text { justify the use of market or hierarchy for organizing } \\
\text { activities in foreign markets }\end{array}$ & $\begin{array}{l}\text { R. Coarse (1937), } \\
\text { O. Williamson (1963, 1975), } \\
\text { (Anderson et Gatignon (1986), } \\
\text { (Contractor et Kundu (1998), } \\
\text { Burton, Cross et Rhodes (2000), } \\
\text { Chen \& Hu (2002) }\end{array}$ \\
\hline & $\begin{array}{l}\text { Eclectic paradigm of } \\
\text { Dunning }\end{array}$ & $\begin{array}{l}\text { Approach that links the factors of firm market to } \\
\text { suggest a theory of international production }\end{array}$ & $\begin{array}{l}\text { (Dunning, 1998; Dunning, 2009; } \\
\text { Agarwal et Ramaswami, 1992; } \\
\text { Driscoll et Paliwoda, 1997) }\end{array}$ \\
\hline & Theory of network & $\begin{array}{l}\text { Approach considering the networks of relationships as } \\
\text { the defining dimension of the internationalization } \\
\text { process, access to critical information they provide }\end{array}$ & $\begin{array}{l}\text { Johanson et WFDIersheim-Paul } \\
\text { (1975), Johanson et Vahlne (1977; } \\
\text { 1990), Kogut et Singh (1988) }\end{array}$ \\
\hline Resources & Resource-based theory & $\begin{array}{l}\text { Analytical approach to international development of } \\
\text { the company by the financial and managerial resources } \\
\text { it has }\end{array}$ & Mutinelli et Piscitello (1998) \\
\hline
\end{tabular}




$$
\begin{aligned}
& \text { Theory based on the } \\
& \text { resources and } \\
& \text { organizational capacity }
\end{aligned}
$$

Ethics
Approach specified in an evolutionary perspective of

international development, the resources and

opportunities for transfer and combination of

knowledge outside the domestic sphere

proposals for new business models challenging the decision on a new role within the company
Kogut \& Zander (1993), Erramili, Agarwal \& Dev (2002)

(Yunus et Weber, 2009; Fontaine et Pauchant, 2009; Pichon, Alain 2009).

Similarly, any companies can use to choose their investment site. Thus, the review of scientific articles has allowed us to retain all the variables used for the selection of sites by companies (see Table 1 on the preceding page). However, we wish to emphasize that in another upcoming article, we will present the point of view of firms in relation to the use of these variables.

\section{Conclusion}

While the Canadian economy is among the fastest growing, it nevertheless remains imperative to implement strategies to maintain and enhance the economic performance. Many articles studies on attracting investment to Canada. But few have shown a genuine interest in the topic of management of the attraction of these investments. Providing such a managerial tool has been our objective here. This study has the advantage of highlighting the major trends in policies and strategies for attracting FDI in Canada. We cited the specific cases and enforcement practices. The innovation of the research lies in the fact that it is used in previous studies in the field of attracting FDI to provide its contributions. The theoretical (theoretical basis) and practical (analysis grid) contributions proposed are relevant in that they provide more tools to businesses and officials responsible for the attraction of FDI in various management levels in public administration and the Canadian public sector. Also, companies can equally use the grid to learn about the potential risks and benefits posed by the country they would choose for their future investments. In this paper, we wanted - in our quest for knowledge - to emphasize the need for better management of the attraction by offering an assessment grid in the end. In this sense, the practical contributions represent its overwhelming interest.

The results of this study on FDI attraction to Canada must be viewed in the light of its limitations. Since the methodology is not systematic, it is possible to lack some papers some relevant papers for deep analysis. We are aware, the selected references are not completely representative the studies on FDI attraction in Canada. This study needs to be tested by larger samples with mixed or quantitative approaches. Some future research could examine more closely the assessment of the current Canadian strategy for FDI attraction by integrating different components of this FDI policy attraction. Furthermore, we propose that the assessment grid and the suggestions in the article need to be tested. Since this study could not be considered as universal, it possible to replicate the theoretical framework in other regions to check its coherence and the consistency. It is worth mentioning that the results of this research cannot be extrapolated to the case of other countries, because the theoretical framework is mainly based on the Canadian case. These limitations showed that more ideas need to be developed in order to test the proposed framework, and this is highly depend on previous quantitative studies.

\section{References}

Acemoglu, D., \& Robinson, J. A. (2005). Economic origins of dictatorship and democracy. Cambridge University Press.

Allee, T., \& Peinhardt, C. (2010). Delegating differences: Bilateral investment treaties and bargaining over dispute resolution provisions. International Studies Quarterly, 54(1), 1-26.

Amewokunu, Y., \& Su, Z. (2009). Repenser l'évaluation du risque-pays dans le contexte de la mondialisation. Management International/Gestiòn Internacional/International Management, 13(2), 35-52.

Aussilloux, V. (1997). Investissements directs, tarifs douaniers et emplois: une modélisation en termes d'équilibre de Stackelberg. Commerce Nord-Sud, migration, délocalisation: les effets sur les salaires et l'emploi, Economica, 102-118.

Barthel, F., Busse, M., \& Neumayer, E. (2010). The impact of double taxation treaties on foreign direct investment: evidence from large dyadic panel data. Contemporary Economic Policy, 28(3), 366-377.

Bevan, A. A., \& Estrin, S. (2004). The determinants of foreign direct investment into European transition economies. Journal of Comparative Economics, 32(4), 775-787.

Birkinshaw, J., Braunerhjelm, P., Holm, U., \& Terjesen, S. (2006). Why do some multinational corporations relocate their headquarters overseas? Strategic Management Journal, 27(7), 681-700. 
Blonigen, B. A. (2005). A review of the empirical literature on FDI determinants. Atlantic Economic Journal, 33(4), 383-403.

Brossard, H. L. (1998). Information sources used by an organization during a complex decision process: an exploratory study. Industrial Marketing Management, 27(1), 41-50.

Burke, L. A., \& Hutchins, H. M. (2007). Training transfer: An integrative literature review. Human resource development Review, 6(3), 263-296.

Busse, M., Königer, J., \& Nunnenkamp, P. (2010). FDI promotion through bilateral investment treaties: More than a bit? Review of World Economics, 146(1), 147-177.

Casillas, J. C., \& Acedo, F. J. (2013). Speed in the internationalization process of the firm. International Journal of Management Reviews, 15(1), 15-29.

Castells, M. (2011). The rise of the network society: The information age: Economy, society, and culture (Vol. 1). Wiley.

Deblock, C., \& Rioux, M. (2010). From economic dialogue to CETA: Canada's trade relations with the European Union. International Journal, 39-56.

Dunning, J. H. (2009). Location and the multinational enterprise: John Dunning's thoughts on receiving the Journal of International Business Studies 2008 Decade Award. Journal of International Business Studies, 40(1), 20-34.

Fabrizio, C. (1994). La dimension culturelle du développement.

Francis, A. P. J., \& Zheng, A. P. C. (2009). An institutional perspective on foreign direct investment. Management International Review, 49(5), 565-583.

Gadille, M., Méhaut, P., \& Courault, B. (2013). Compétences et régulation des marchés du travail dans les pôles de compétitivité: le cas du pôle Pégase. Revue d'Économie Régionale \& Urbaine, (2), 339-361.

Hatem, F. (2004). Investissement international et politiques d'attractivité. Economica.

Hirschman, A. O. (1988). The strategy of economic development. Westview Press Boulder.

Johanson, J., \& Vahlne, J. E. (1977). The internationalization process of the firm-a model of knowledge development and increasing foreign market commitments. Journal of International Business Studies, 8(1), 23-32.

Johanson, J., \& Wiedersheim-Paul, F. (1975). The internationalization of the firm-four swedish cases 1. Journal of Management Studies, 12(3), 305-323.

Johnson, L., Toledano, P., Strauss, I., \& James, S. (2013). Background Paper on Investment Incentives: The good, the bad and the ugly: Assessing the costs, benefits and options for policy reform.

Kalamova, M. M., \& Konrad, K. A. (2010). Nation Brands and Foreign Direct Investment. Kyklos, 63(3), 400-431.

Kogut, B. (1988). Joint ventures: Theoretical and empirical perspectives. Strategic Management Journal, 9(4), 319-332.

Kotabe, M. (1993). The promotional roles of the state government and Japanese manufacturing direct investment in the United States. Journal of Business Research, 27(2), 131-146.

Kristof, A. L. (1996). Person-organization fit: An integrative review of its conceptualizations, measurement, and implications. Personnel Psychology, 49(1), 1-49.

Kumar, N. (1998). Technology generation and technology transfers in the world economy: recent trends and implications for developing countries. Science Technology \& Society, 3(2), 265-306.

Kumar, N. (2009). Liberalisation, Foreign Direct Investment Flows and Development. Readings in Indian Agriculture and Industry, 465.

Kumar, N., \& Siddharthan, N. S. (2013). Technology, Market Structure and Internationalization: Issues and Policies for Developing Countries. Routledge.

Mayer, T., \& Mucchielli, J. L. (1999). La localisation à l'étranger des entreprises multinationales. Une approche d'économie géographique hiérarchisée appliquée aux entreprise japonaises en Europe. Economie et Statistique, 326(1), 159-176. 
McCann, P., \& Mudambi, R. (2004). The location behavior of the multinational enterprise: Some analytical issues. Growth and Change, 35(4), 491-524.

Melville, N., Kraemer, K., \& Gurbaxani, V. (2004). Review: Information technology and organizational performance: An integrative model of IT business value. MIS Quarterly, 28(2), 283-322.

Monaghan, S. (2012). Attraction and Retention of Foreign Direct Investment (FDI): The Role of Subnational Institutions in a Small, Highly Globalised Economy. Irish Journal of Management, 31(2).

Mucchielli, J. L. (1991). Alliances stratégiques et firmes multinationales: une nouvelle théorie pour de nouvelles formes de multinationalisation. Revue D'économie Industrielle, 55(1), 118-134.

Mucchielli, J. L. (1998). Multinationales et mondialisation (Vol. 41). Éd. du Seuil.

Musolesi, A. (2006). Recherche, productivité et externalités internationales: une analyse économétrique sur données de panel pour un groupe de pays de l'OCDE: LEG, Laboratoire d'Economie et de Gestion, CNRS, Université de Bourgogne.

Mutinelli, M., \& Piscitello, L. (1998). The entry mode choice of MNEs: an evolutionary approach. Research Policy, 27(5), 491-506.

Myrdal, G., \& Sitohang, P. (1957). Economic theory and under-developed regions.

Schuler, R. S., Dowling, P. J., \& De Cieri, H. (1993). An integrative framework of strategic international human resource management. Journal of Management, 19(2), 419-459.

Shaver, J. M. (1998). Do foreign-owned and US-owned establishments exhibit the same location pattern in US manufacturing industries? Journal of International Business Studies, 469-492.

Sinanagić, M., Čivić, B., \& Kamarić, A. (2012). Institutional marketing communications in role of attracting foreign direct investments to bosnia and herzegovina. Economic Review: Journal of Economics \& Business/Ekonomska Revija: Casopis za Ekonomiju i Biznis, 10(1).

Thomas, K. P. (2007). Investment incentives: Growing use, uncertain benefits, uneven controls. Interntional Institute for Sustainable Development= Institut international du développement durable.

Thomas, K. P. (2011). Regulating Investment Attraction: Canada's Code of Conduct on Incentives in a Comparative Context. Canadian Public Policy, 37(3), 343-357.

Vahlne, J.-E., Ivarsson, I., \& Johanson, J. (2011). The tortuous road to globalization for Volvo's heavy truck business: Extending the scope of the Uppsala model. International Business Review, 20(1), 1-14.

Wilkinson, T. J., \& Brouthers, L. E. (2000). Trade shows, trade missions and state governments: Increasing FDI and high-tech exports. Journal of International Business Studies, 725-734.

Woodward, A. R. (2009). Chapter Thirteen The Impact of US Subsidies on West African Cotton Production. In A. R. Woodward (Ed.), Case Studies in Food Policy for Developing Countries: Institutions and international trade policies (Vol.3, p. 171).

Woolcock, S. (2006). Trade and investment rule-making: the role of regional and bilateral agreements. United Nations University.

\section{Notes}

Note 1. Minister of International Trade and Minister for the Asia-Pacific Gateway. http://www.international.gc.ca/media_commerce/comm/news-communiques/2012/10/07a.aspx?lang=eng\& view $=\mathrm{d}$ (Retrieved 11 February 2013)

Note 2. Government House Leader Peter Van Loan (Canada). http://news.nationalpost.com/2012/12/06/van-loan-apologizes-for-dropping-inappropriate-word-into-verbal-dust up-with-ndp-but-may-still-face-formal-complaint/ (Journal National Post, retrieved 11 February 2013)

Note 3. http://www.unctad-docs.org/

\section{Copyrights}

Copyright for this article is retained by the author(s), with first publication rights granted to the journal.

This is an open-access article distributed under the terms and conditions of the Creative Commons Attribution license (http://creativecommons.org/licenses/by/3.0/). 